\title{
SISTEM INFORMASI ATLET DILINGKUNGAN DINAS PEMUDA DAN OLAHRAGA KABUPATEN KATINGAN BERBASIS MOBILE
}

\author{
${ }^{1}$ Ferdiyani Haris, ${ }^{2}$ Afrianthonny \\ ${ }^{1}$ Sistem Informasi, ${ }^{2}$ Teknik Informatika - STMIK Palangkaraya \\ Jl. G. Obos No. 114 Palangkaraya, Kalimantan Tengah \\ E-mail : 'sabila006@gmail.com, ${ }^{2}$ rependos.bjb@gmail.com
}

\begin{abstract}
ABSTRAK
Perkembangan komputer sekarang ini sangat pesat dan digunakan diberbagai bidang kehidupan. Biasanya komputer digunakan untuk menghasilkan berbagai informasi penting guna meningkatkan kinerja dari organisasi, perusahaan atau lembaga agar pekerjaan yang dilakukan lebih efektif dan efisien hal ini disebabkan komputer melakukan proses informasi yang cepat. Untuk menjaga kelancaran, memantau dan juga mempermudah tugas pengelolaan data maka hal ini perlu dibuat sebuah sistem pengelolaan data atlit Kabupaten Katingan berbasis Code Igniter. Pengembangan sistem menggunakan Adobe Dreamweaver, script PHP dan database MySql yang didukung dengan CSS, dan Bootstrap yang dapat digunakan dalam sistem operasi Windows. Metode yang digunakan dalam pengumpulan data seperti wawancara, observasi, dan studi pustaka. Wawancara yaitu cara mengumpulkan data dengan mengadakan tanya jawab langsung dengan bagian yang berhubungan dengan objek yang diteliti. Observasi yaitu pengamatan langsung mengenai penyampaian informasi secara manual yang sedang berjalan. Studi pustaka adalah pengumpulan data dengan mempelajari buku atau literatur-literatur mengenai desain suatu sistem yang diharapkan menghasilkan sebuah aplikasi untuk mengelola data atlit Kabupaten Katingan berbasis code igniter.
\end{abstract}

Kata Kunci : Aplikasi, atlit, Code Igniter, Pengelolaan Data

\begin{abstract}
The development of the computer is now very rapid and used in various areas of life. Typically, computers are used to produce important information to improve the performance of organizations, companies or institutions to make the work done more effectively and efficiently because the computer is processing information Fast. To maintain the smoothness, monitoring and also facilitate the task of data management, it is necessary to create a data management system for Code of Katingan-based Catalan regency. System development uses Adobe Dreamweaver, a PHP script and MySql database supported with CSS, and Bootstrap that can be used in Windows operating systems. Methods used in data collection such as interviews, observations, and library studies. Interviews are how to collect data by holding frequently asked questions with sections related to the objects being researched. Observation is a direct observation of the ongoing delivery of information. The study of the library is the collection of data by studying books or literature on the design of a system that is expected to produce an application to manage the data of the Catalan Regency based on code igniter.
\end{abstract}

\section{Keywords: application, athlete, Code Igniter, Data Management}

\section{Pendahuluan}

Dinas Pemuda dan Olahraga Kabupaten Katingan merupakan salah satu kantor pemerintah yang ada di Kabupaten Katingan yang bertanggung jawab dalam mengembangan dan memberdayaan para pemuda terutama dalam bidang prestasi olahraga, Seperti hal nya kantor pemerintah yang lain Dinas Pemuda dan Olahraga mempunyai data-data penting yang masih sebagian besar ada dicatat pada buku besar dan Microsoft Excel mengenai data atlit dan cabang olahraga yang dibina. Namun pengolahan data seperti ini kadang tidak efektif dan efisien dalam pencarian data karena harus membuka arsip-arsip lama dari pencatatan buku agenda dan membutuhkan waktu yang lama dalam pencariannya serta sering kali menimbulkan masalah karena adanya arsip- 


$$
\begin{array}{c|l|l}
\text { Jurnal Sains Komputer dan Teknologi Informasi } & \text { Page } \\
\text { e-issn: 2655-7460. Volume i No.2, Mei } 2019 & 1-5
\end{array}
$$

arsip yang hilang, tercecer dan lupa dicatat di buku, hal ini berdampak pada pemberian informasi yang menjadi tidak tepat waktu. Salah satu informasi yang sering kali terlambat dan tidak efektif dalam pengelolaannya adalah pengelolaan data atlet terutama atlet yang berprestasi pada cabang olahraga tertentu.

Guna mengatasi permasalahan pengelolaan data atlet secara lebih cepat maka perlu adanya sebuah sistem informasi yang berbasis mobile, di mana proses pengumpulan dan pencarian data akan lebih mudah di dapat.

\section{Kajian Teori}

\section{A. CodeIgniter}

Menurut Septian (2011:12), Codeigniter adalah aplikasi open source yang berupa Framework dengan model MVC (Model, View, Controller) untuk membangun website dinamis dengan menggunakan PHP. Code Igniter memudahkan developer untuk membuat aplikasi web dengan cepat dan mudah dibandingkan dengan membuatnya dari awal.

Menurut Riyanto (2011:13), CodeIgniter adalah sebuah framework yang digunakan untuk membuat sebuah aplikasi berbasis web yang disusun dengan menggunakan bahasa PHP. Di dalam CI terdapat beberapa macam kelas (class) yang berbentuk library dan helper. Keduanya berfungsi untuk membantu pemrogram (programmer) dalam mengembangkan aplikasinya.

\section{B. Twitter Bootstrap}

Menurut Madcoms (2011:4), Twitter Bootstrap adalah sebuah alat bantu membuat tampilan halaman Website yang dapat mempercepat pekerjaan seorang pengembang Website ataupun pendesain halaman Website. Sesuai namanya, Website yang dibuat dengan alat bantu ini memiliki tampilan halaman yang sama atau mirip dengan tampilan halaman Web sesuai dengan kebutuhan.

\section{Xampp}

Menurut Riyanto (2011:9), XAMPP merupakan paket PHP dan MySQL berbasis Open Source, yang dapat digunakan sebagai Tool pembantu pengembangan aplikasi berbasis PHP.

Fungsinya adalah sebagai server yang berdiri sendiri (localhost), yang terdiri atas program Apache HTTP Server, MySQL Database, dan penerjemah bahasa yang ditulis dengan bahasa pemrograman PHP dan Perl. Nama XAMPP merupakan singkatan dari $\mathrm{X}$ (empat sistem operasi apapun), Apache, MySQL, PHP, dan Perl. Program ini tersedia dalam GNU (General Public License) dan bebas, merupakan Web Server yang mudah digunakan yang dapat melayani tampilan halaman $W e b$ yang dinamis.

\section{Adobe Dreamweaver CS6}

Menurut Sadeli (2011:11), Dreamweaver merupakan Software aplikasi yang digunakan sebagai HTML, editor profesional untuk mendesain Web secara Visual.

Adobe Dreamweaver merupakan aplikasi penyunting untuk halaman Web yang dikeluarkan oleh Adobe Systems yang sebelumnya dikenal dengan Macromedia Dreamweaver keluaran Macromedia. Adobe kembali mengeluarkan varian terbaru dari Dreamwevear yaitu Dreamwevear CS6.

\section{Perancangan Sistem}

Berdasarkan tahapan pada pemodelan sistem yang penulis gunakan, maka penulis akan menjelaskan tentang Unifield Modelling Language (UML).

\section{A. Perancangan Proses}

Pada tahapan ini akan menguraikan dalam beberapa diagram yaitu use case diagram, activity diagram, sequence diagram dan class diagram.

\section{1) Use Case Diagram}

Diagram use case mendeskripsikan sebuah interaksi antara satu atau lebih aktor dengan sistem yang akan dibuat. Diagram use case digunakan untuk mengetahui fungsi apa saja yang ada di dalam sebuah sistem dan siapa saja yang berhak menggunakan fungsifungsi tersebut. Sebuah use case merepresentasikan sebuah interaksi antara aktor (user atau sistem lainya) dengan sistem. Use case menjelaskan secara sederhana fungsi sistem dari sudut pandang user.

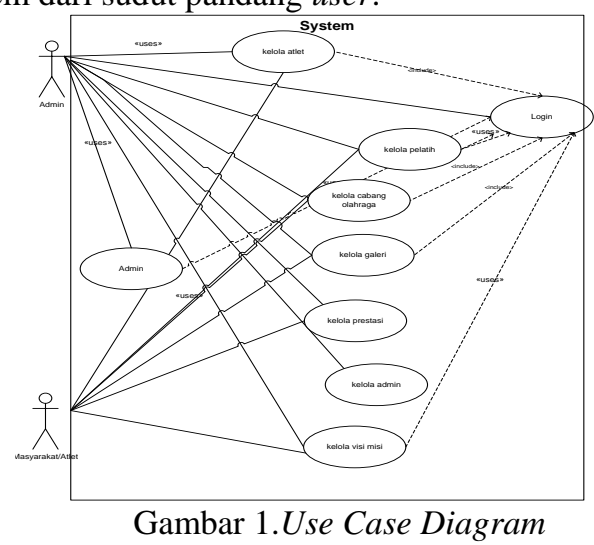

Terdapat 2 aktor yaitu admin, dan masyarakat/atlet. Admin melakukan login terlebih dahulu untuk dapat mengelola sistem. Setelah admin selesai mengelola sistem input 
maka akan menghasilkan output berupa informasi yang dapat dilihat oleh atlet. Sistem ini masyarakat/atlet tidak perlu login untuk dapat melakukan akses website.

\section{2) Class Diagram}

Class diagram menggambarkan struktur dan deskripsi class, package dan objek beserta hubungan satu sama lain seperti containment, pewarisan, asosiasi, dan lain-lain. Class diagram dapat dilihat pada gambar 2 :

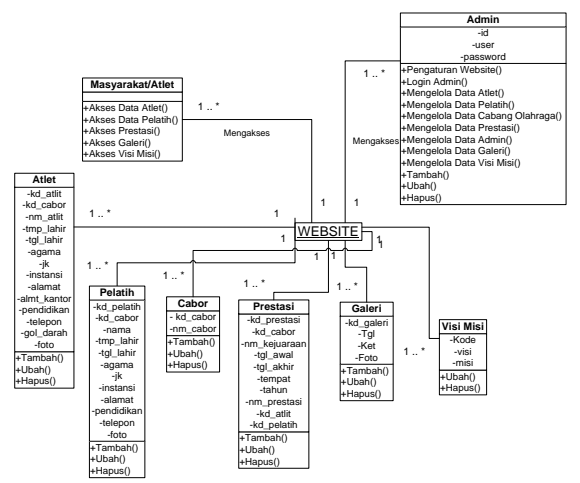

Gambar 2. Class Diagram

\section{B. Pembuatan tabel}

Langkah selanjutnya adalah membuat tabel dalam database. Dalam database ini akan dibuat sebanyak tujuh buah tabel database sebagai tempat untuk meyimpan data yang dikelola dalam aplikasi, tabel-tabel tersebut antara lain sebagai berikut :

1) Tabel Admin

Tabel admin digunakan untuk meyimpan data admin yang mengolah semua data pada website ini, juga sebagai akses untuk login ke halaman admin.

Tabel 1. Struktur Tabel Admin

\begin{tabular}{ll}
\hline \multicolumn{1}{c}{ Field } & \multicolumn{1}{c}{ Type data } \\
\hline Id* & $\operatorname{Int}(2)$ \\
\hline user & Varchar(30) \\
\hline password & Varchar(50) \\
\hline
\end{tabular}

2) Tabel Data Atlet

Tabel aset untuk meyimpan data atlet di Kabupaten Katingan.

Tabel 2. Struktur Tabel Atlet

\begin{tabular}{ll}
\hline \multicolumn{1}{c}{ Field } & Type data \\
\hline kd_atlit* & varchar(10) \\
\hline kd_cabor** & $\operatorname{Int}(5)$ \\
\hline nm_atlit & varchar(50) \\
\hline
\end{tabular}

\begin{tabular}{ll}
\hline tmp_lahir & varchar(30) \\
\hline tgl_lahir & Date \\
\hline Agama & varchar(10) \\
\hline JK & varchar(1) \\
\hline Instansi & varchar(30) \\
\hline Alamat & text \\
\hline almt_kantor & text \\
\hline pendidikan & varchar(5) \\
\hline telepon & varchar(12) \\
\hline foto & varchar(30) \\
\hline
\end{tabular}

3) Tabel Pelatih

Tabel pelatih digunakan untuk meyimpan data pelatih yang akan diinformasikan pada halaman web.

Tabel 3. Struktur Tabel Pelatih

\begin{tabular}{ll}
\hline \multicolumn{1}{c}{ Field } & \multicolumn{1}{c}{ Type data } \\
\hline kd_pelatih* & kd_pelatih* \\
\hline kd_cabor** & kd_cabor** \\
\hline nama & nama \\
\hline tmp_lahir & tmp_lahir \\
\hline tgl_lahir & tgl_lahir \\
\hline Agama & Agama \\
\hline JK & JK \\
\hline Instansi & Instansi \\
\hline Alamat & Alamat \\
\hline Alamat_instansi & Alamat_instansi \\
\hline pendidikan & pendidikan \\
\hline telepon & telepon \\
\hline Foto & Foto \\
\hline
\end{tabular}

4) Tabel Galeri

Tabel galeri merupakan tabel database yang akan menyimpan koleksi foto kegiatan atau gambar lain yang akan diinformasikan kepada masyarakat.

Tabel 4. Struktur Galeri

\begin{tabular}{|c|c|}
\hline Field & Type data \\
\hline kd galeri $*$ & Int(10) \\
\hline$\underline{\mathrm{Tgl}}$ & Datetime \\
\hline Ket & Text \\
\hline Foto & $\underline{\text { Text }}$ \\
\hline
\end{tabular}

5) Tabel Cabang Olahraga

Tabel cabang olahraga merupakan tabel yang menyimpan data cabang olahraga.

Tabel 5. Struktur Tabel Cabang Olahraga

\begin{aligned} & \hline$\underline{\text { Field }} \multicolumn{1}{c}{$ Type data } \\ & \hline$\underline{\text { kd_cabor* }} \underline{\operatorname{Int}(5)} \\ &$\hline nm_cabor $\operatorname{varchar}(50) \\ &$\hline\end{aligned}


6) Tabel Prestasi

Tabel prestasi merupakan tabel database yang menyimpan data prestasi atlet.

\section{Tabel 6. Struktur Tabel Prestasi}

\begin{tabular}{|c|c|}
\hline Field & Tipe data \\
\hline kd_prestasi $*$ & $\operatorname{Int}(10)$ \\
\hline kd_cabor $* *$ & $\operatorname{Int}(5)$ \\
\hline nm_kejuaraan & Text \\
\hline tgl_awal & Date \\
\hline tgl_akhir & Date \\
\hline tempat & Varchar(50) \\
\hline tahun & Year(4) \\
\hline nm_prestasi & Text \\
\hline kd_atlit** & Varchar(10) \\
\hline kd_pelatih** & Varchar(10) \\
\hline kd_prestasi * & $\operatorname{Int}(10)$ \\
\hline
\end{tabular}

\section{7) Tabel VM (Visi Misi)}

Tabel vm merupakan tabel database yang menyimpan data visi misi.

\begin{tabular}{ll} 
& Tabel 9. Struktur VM \\
\hline \multicolumn{1}{c}{ Field } & \multicolumn{1}{c}{ Tipe data } \\
\hline Kode* & Int(1) \\
\hline Visi & Text \\
\hline Misi & Text \\
\hline
\end{tabular}

\section{Perancangan Antar Muka}

\section{1) Halaman pengunjung}

Halaman utama website merupakan halaman website yang tersedia dan diakses oleh pengunjung. Adapun tahapan ini akan dibuat file-file PHP untuk halaman utama. Dapat dilihat pada gambar 3. Halaman Pengunjung.

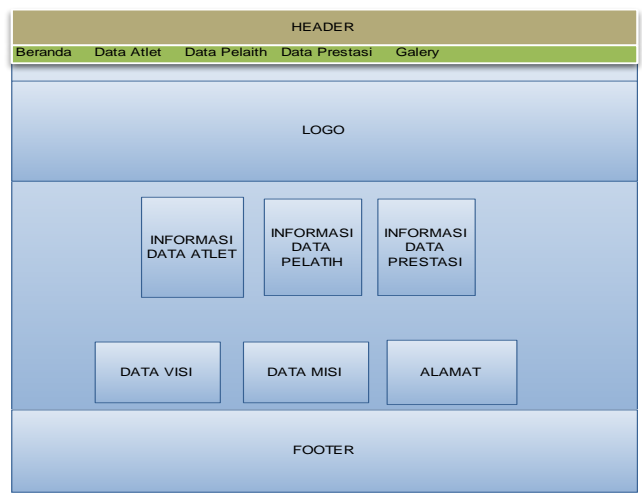

Gambar 3. Halaman Indeks Pengunjung

\section{2) Halaman administrator}

Merupakan halaman administrator yang hanya dapat diakses oleh admin untuk mengolah data dan informasi yang ada pada halaman website. Halaman ini dikhususkan untuk pengelola atau admin saja. Rancangan menu admin dapat dilihat pada gambar 4 .

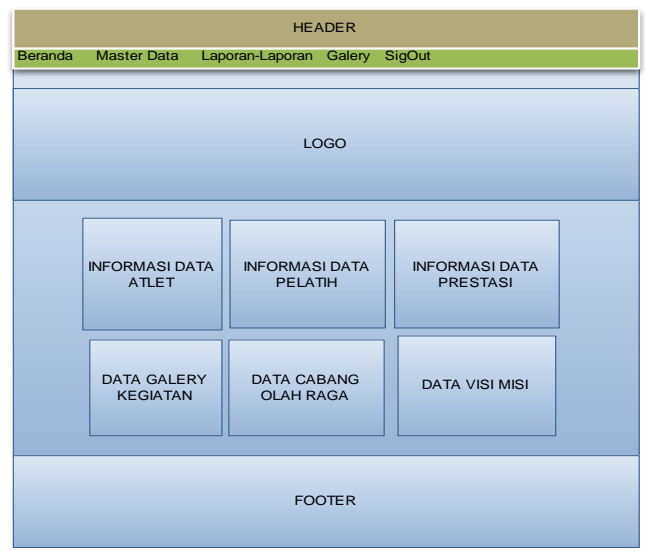

Gambar 4. Halaman Admin

\section{Implementasi Dan Pembahasan}

Implementasi merupakan tahap pengembangan rancangan menjadi kode program dan menjalankan kode progam agar website dapat berjalan sesuai rancangan.

\section{A. Halaman Utama Pengunjung}

Pada halaman utama pengunjung menampilkan menu, diantaranya adalah data atlet, data pelatih, data prestasi, kegiatan, dan hubungi kami. Dapat dilihat pada gambar 6.

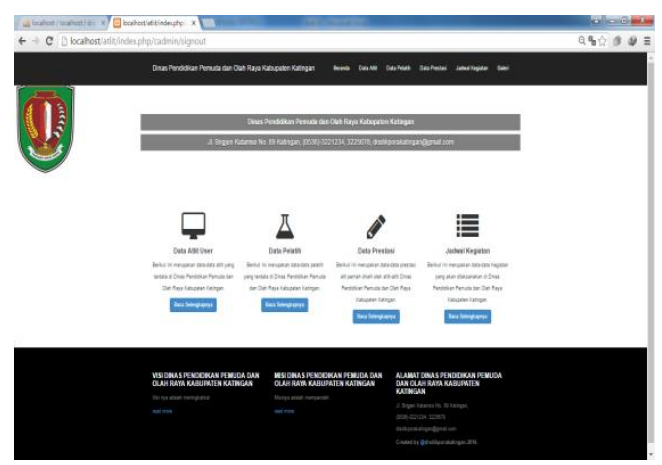

Gambar 6. Halaman Utama Pengunjung

\section{B. Halaman Utama Admin}

Halaman utama admin berisi beranda, dan menu untuk mengelola data atlet, data pelatih, data prestasi, galeri kegiatan, data cabang olahraga, data visi misi, data jadwal kegiatan, serta menu keluar. Berikut adalah gambaran halaman utama admin dapat dilihat pada gambar 7 . 


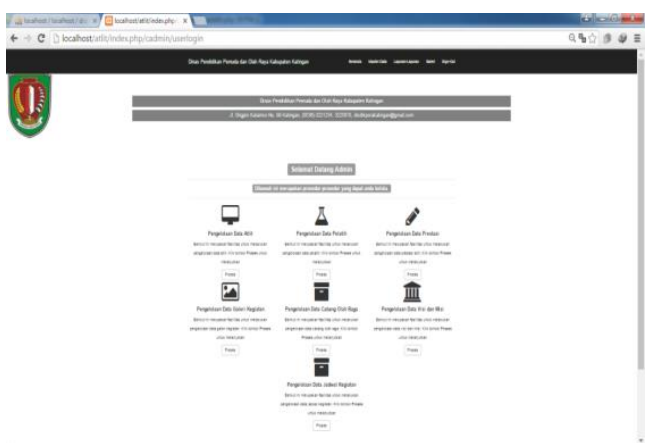

Gambar 7. Halaman Utama Admin

\section{Kesimpulan dan Saran}

A. Kesimpulan

1) Aplikasi Pengelolaan data atlit di Kabupaten Katingan yang dapat mempermudah pengelolaan data atlit dan memberikan informasi kepada masyarakat mengenai data atlit, kegiatan serta prestasi yang didapatkan oleh atlit di Kabupaten Katingan.

2) Sistem yang dikembangkan ini dibuat secara dengan tampilan yang mudah digunakan dan dioperasikan baik bagi admin atau pengguna sehingga dalam mengelola dan mendapatkan informasi mengenai data-data atlet, prestasi, pelatih dan galeri kegiatan di lingkungan Kabupaten Katingan.

\section{B. Saran}

1) Sistem ini hendaknya lebih ditingkatkan lagi dari segi penyajian informasi yang lebik banyak baik berupa pembagian data atlit percabang olahraga, informasi mengenai rencana anggaran biaya pembinaan, keadaan keuangan pembinaan percabang olahraga dan kegiatan latihan yang dilakukan atlit, sehingga penyajian informasinya dapat lebih baik dan lengkap.

2) Untuk mencegah rusaknya atau hilangnya data dalam file database, sebaiknya dilakukan back up secara berkala dan scan terhadap virus yang merusak.

\section{Daftar Pustaka}

Haris, Ferdiyani. 2018. Rancang Bangun Aplikasi Ensiklopedia Berbasis Android. Jurnal Sains Komputer dan Teknologi Informasi. Vol 1 Issue 1 e-ISSN 26557460 . https://doi.org/10.33084/jsakti.v1i1.448

Hendrayudi, 2009. Penuntun Praktis Belajar $S Q L$, Andi. Yogyakarta

Hendry. 2003. Sistem Informasi Manajemen, Edisi Bahasa Indonesia, Jilid I, PT Prenhallindo, Jakarta.
Jogiyanto. 2005. Analisis dan Desain Sistem Informasi, Andi, Yogyakarta.

Kamus Besar Bahasa Indonesia, 2005. Graha Ilmu, Jakarta

Madcoms. 2009. Aplikasi Program PHP + MySQL Untuk Membuat Website Interaktif, Andi, Yogyakarta.

Riyanto 2011, Membuat Sendiri Aplikasi Ecommerce dengan PHP dan MySQL Menggunakan Codeigniter dan JQuery. Andi, Yogyakarta.

Sam'ani. 2018. Rancang Bangun Aplikasi Pengawasan Dan Pengendalian Komputer Laboratorium Multimedia STMIK Palangkaraya. Jurnal Sains Komputer dan Teknologi Informasi. Vol 1 Issue 1 e-ISSN 2655-7460. https://doi.org/10.33084/jsakti.v1i1.548

Septian Gugun., 2011. "Trik Pintar Menguasai CodeIgniter”, Jakarta : PT Alex Media Komputindo.

Sondakh, 2009. "Olahraga Prestasi”, Elex Media Komputindo, Jakarta.

Sadeli, Muhammad. 2011. 7 Jam Belajar Interaktif Dreamweaver CS5 untuk Orang Awam: Maxikom, Palembang.

Tutang. 2001. Aplikasi Manajemen Database Pendidikan Berbasis Web Dengan PHP dan MySQL, Andi, Yogyakarta. 